\title{
Creative Analysis of Brand Placement in Game Contents
}

\author{
Yong-Jae Lee \\ College of Digital Entertainment \\ Tongmyong University, Busan, 608-711, South Korea
}

\begin{abstract}
This research attempts to analyze brand placement in game. Brand placement, being acclaimed as a new beneficiary model in game industry, is raising important mean of advertising. For development of game industry, the interdisciplinary study between game and advertising is indispensible. Therefore, the purpose of this study is to find creative types of brand placement in game for illuminating how advertising works in game contents. The results showed three types of brand placement in game. They are contextual type, prominent type and independent type. Contextual type is one where the brand is present within the game contents without being formally expressed: it plays a passive role. Prominent type is one where the brand is present within the game contents with being formally expressed: it plays an active role. Independent type is one where the brand is present within the game contents with being formally expressed but it is not related with the program: it plays an additional role. The research showed, among these three types, a prominent type is becoming mainstream of brand placement in game. In other words, the prominent type of brand placement is the most effective beneficial alternative in game industry.
\end{abstract}

Keywords: Brand Placement, Game Contents, Creative Analysis, Interdisciplinary Study, Beneficial Model

\section{INTRODUCTION}

In recent years there has been an increase the research on the brand placement in game. Rapid growth of game industry has spurred active researches on brand placement as a new beneficiary model. Now brand placement is emerging as the leading beneficiary model in game industry because interest has increased about the ways to effectively insert sponsor's brand name on game contents. Brand placement has been used to be a mean of promotion in marketing and it has been introduced into the game contents.

In game, which is leading the multimedia industry, the boundary between the virtual reality and the real world is getting blurred and the need for a new beneficiary model is urgent. Accordingly, brand placement, which had almost exclusively been used in movies and TV programs as a tool for marketing communication, has been observed more and more frequently in games as well.

Passive forms of brand placement existed in the past, and brands were occasionally exposed in the background of game. In recent years, however, active sense of brand placement is evolving at a rapid pace not only for additional entertainment as with accessory characters, but also as a beneficiary model.

This study, which is interdisciplinary in nature, could be found in the fact that it is the pioneering work which applies

\footnotetext{
*Corresponding author.E-mail : leeyj@tu.ac.kr

Manuscript received Mar.07, 2011 ; accepted Mar.22, 2011
}

marketing concepts to the game industry. In marketing fields, brand placement is widely accepted which aims at overcoming the weaknesses of conventional commercials which are to low attention-gathering.

In particular, we are witnessing actively brand placement utilized in all areas of the multimedia industry including games, movies, TV, books, and music videos. Companies use brand placement to expose and promote their brand at a relatively low cost when they insert their products, brands and logos inside the program and its effects of exposure and brand promotion are maximal considering relatively low cost required compared to other commercials.

This research attempts to classify the types of brand placement appearing on game in accordance with its contents creativity. In other words, the important of this study is that the effects of marketing are depending on the creativity of brand placement appearing on game.

The exposure types of brand placement generally include on-set placement and creative placement. And it has been proven through former researches that different brand placement types bring about different advertising effects[1]-[4]. Therefore, the purpose of this study is to seek the creative types of brand placement appearing on the game contents.

The research of this kind might shed some light on further effects of brand placement as well as on the exposure strategies for important messages in game contents. To summarize, the focus of the research is to come up with the optimal model for creative types of brand placement by analyzing game contents. 


\section{THEORETICAL DISCUSSIONS}

\subsection{Researches on the Brand Placement}

Brand placement(BPL) is defined as a tool of marketing communication which exposes relevant brands or product information in a way to harmonize with the game contents for building up consumers' brand image. In other words, showing the brand in any kinds of media is obviously form of BPL. In recent years the brand placement is becoming an integral part of a marketing communication. And this trend is transferring naturally to advertising industry.

Accordingly, brand placement is the process that integrates an advertiser's brand into selected media, most often television, films, and games. Although the brand is visible, it is often not focus, as it needs to fit almost seamlessly into the context of a scene or story. Brand integration is a special type of brand placement in which the advertiser's brand is central to the plot line.

Brand placement can be audio, visual or print based. Generally, there are three major types of brand placement[5]: paid, in which the BPL is arranged and there is financial compensation: barter, which is also arranged, but the brand serves as compensation: and gratis, in which the placement simply happens, often to strengthen a character profile, or add richness to the plot, audio or printed text.

In recent years there has been an increase the research on the BPL as a mean of promotional method. Researchers have indicated the importance of BPL as an additional element of the promotional mix[6],[7], yet there is scope for further research concerning its practice.

A review of the main areas of research undertaken to date reveals that some studies have focused on particular aspects of BPL such as types of brand used in placements[8], the effects of placement type and exposure time on brand recognition[9], the effect of branded props on consumer behavior[10], and the semantics employed by viewers.[11]

Others have examined BPL in terms of its ethical acceptability[12]. BPL refers to the practice of including a brand name product, package, signage or other trademark merchandise within a motion picture, television show or music video [13].

Turcotte[14] identified three key marketing benefits of BPL. First, BPL has a long life span. Unlike traditional broadcast advertising, which has a very short life span, BPL in successful films benefit from the fact that such films are often distributed internationally, re-broadcast on television and have a virtually eternal life span on video.

Second, the content viewed in the cinema environment is subjected to far fewer distractions than that encountered by the home viewer. Other ads are not competing for the viewers' attention and the distractions of telephones and household chores are not present in the cinema - the audience is essentially a captive one.

Finally, the picture quality, screen size and sound quality of the movie are unmatched by any commercially available home viewing system.
Murdock[15] classifies BPL as either creative or onset. Creative placements occur when a brand appears in the background of a shot. In contrast, on-set placements are displayed more prominently. Prominence may result from the fact that products are consumed or mentioned by one of the leading actors.

The Gupta and Lord[16] study indicates that placements which are prominent generate a higher level of recognition than those which are subtle, a finding which endorses the film studio practice of charging a premium for on-set placements. It is also important to note that, since opportunities to notice a product placement increase with exposure time, brandplacement contracts routinely include a minimum-airtime clause. Thus an understanding of the relative importance of placement type and exposure time in predicting brand recognition had important commercial implications.

Previous research on BPL has mostly been limited to measuring brand recall to assess effectiveness. One of the few empirical studies on BPL indicated that viewers were able to recognize brands placed within a film (Babin and Carder[17]). However, the study only dealt with one form of BPL: the visual appearance of the brand on the screen. Table 1 summarizes more findings of recent investigations of viewers' perception of BPL.

Table 1: Studies on the brand placement [18]

\begin{tabular}{|l|l|l|}
\hline \multicolumn{1}{|c|}{ Study } & \multicolumn{1}{|c|}{ Sample } & \multicolumn{1}{c|}{ Major findings } \\
\hline Karrh et al. & $\begin{array}{l}\text { 97 US and } \\
\text { 97 Singaporean } \\
\text { college } \\
\text { (2001) }\end{array}$ & $\begin{array}{l}\text { Both sets of respondents pay } \\
\text { attention to brands in films and } \\
\text { TV; US respondents pay more } \\
\text { attention to their social identities; } \\
\text { Singaporeans are less likely to } \\
\text { perceive brand appearances as } \\
\text { paid advertising, are more } \\
\text { concerned about ethics of brand } \\
\text { placement and more supportive } \\
\text { of government restrictions on } \\
\text { placement activities. }\end{array}$ \\
\hline $\begin{array}{l}\text { d'Astous } \\
\text { \& Chartier } \\
\text { (2000) }\end{array}$ & $\begin{array}{l}\text { 103 movie- } \\
\text { goers }\end{array}$ & $\begin{array}{l}\text { Degree of perceived integration } \\
\text { of placement in movie scene is } \\
\text { positively linked to liking, but } \\
\text { negatively linked to perceived } \\
\text { unacceptability and has a } \\
\text { negative impact on memory. }\end{array}$ \\
\hline $\begin{array}{l}\text { Gould et al. } \\
\text { (2000) }\end{array}$ & $\begin{array}{l}\text { 204 French and } \\
\text { college } \\
\text { students }\end{array}$ & $\begin{array}{l}\text { Country, product and individual } \\
\text { differences have an impact on the } \\
\text { acceptability of brand placement } \\
\text { and on potential purchase } \\
\text { behavior: country differences } \\
\text { exist, but they are not prohibitive } \\
\text { to following a standardization } \\
\text { strategy; caution is urged for the } \\
\text { placement of ethically-charged } \\
\text { products that seem to generate } \\
\text { similar concerns across countries, } \\
\text { especially in contrast to non- }\end{array}$ \\
\hline
\end{tabular}




\begin{tabular}{|c|c|c|}
\hline & & $\begin{array}{l}\text { ethically charged products; and } \\
\text { individual differences also } \\
\text { persist, often in the form of } \\
\text { complex interactions. }\end{array}$ \\
\hline $\begin{array}{l}\text { Richmond } \\
(2000)\end{array}$ & $\begin{array}{l}36 \text { movie-goers } \\
\text { (18-25 years) }\end{array}$ & $\begin{array}{l}\text { Brand placement susceptible to } \\
\text { all of Lutz's (1985) structural } \\
\text { model of antecedents of ad; mood } \\
\text { determinant exerting greatest } \\
\text { influence, while ad credibility } \\
\text { has little impact apart from in } \\
\text { high-involvement purchasing } \\
\text { situations; positive and negative } \\
\text { cues influencing image of } \\
\text { branded products. }\end{array}$ \\
\hline $\begin{array}{l}\text { DeLorme } \\
\text { \& Reid } \\
(1999)\end{array}$ & $\begin{array}{l}99 \text { movie-goers } \\
\text { (younger/older } \\
\text { frequent/infreq } \\
\text { uent }\end{array}$ & $\begin{array}{l}\text { Regardless of age or movie-going } \\
\text { frequency, respondents are active } \\
\text { participants in the viewing } \\
\text { experience and interpret brands } \\
\text { encountered in movies; brands in } \\
\text { movies symbolized social change } \\
\text { to the older movie-goers and } \\
\text { belonging and security to } \\
\text { younger ones. }\end{array}$ \\
\hline $\begin{array}{l}\text { Gupta \& } \\
\text { Gould } \\
\text { (1997) }\end{array}$ & $\begin{array}{l}1012 \\
\text { college } \\
\text { students }\end{array}$ & $\begin{array}{l}\text { Generally positive attitudes } \\
\text { towards practice of brand } \\
\text { placement; yet certain product } \\
\text { categories such as alcohol, } \\
\text { cigarettes and guns are judged } \\
\text { less acceptable for brand } \\
\text { placement than others; individual } \\
\text { differences in gender, movie- } \\
\text { viewing frequency, and relevant } \\
\text { attitudes found to affect } \\
\text { acceptability of brand } \\
\text { placements. }\end{array}$ \\
\hline $\begin{array}{l}\text { Baker \& } \\
\text { Crawford } \\
(1995)\end{array}$ & $\begin{array}{l}43 \text { postgraduate } \\
\text { students }\end{array}$ & $\begin{array}{l}\text { Most respondents have a neutral } \\
\text { attitude towards brand placement. }\end{array}$ \\
\hline $\begin{array}{l}\text { Babin \& } \\
\text { Carder } \\
\text { (1996a) }\end{array}$ & $\begin{array}{l}108 \text { college } \\
\text { students }\end{array}$ & $\begin{array}{l}\text { Brand salience significantly } \\
\text { greater for treatment group than } \\
\text { control group for more than a } \\
\text { quarter of the brand placements; } \\
\text { no significant differences found } \\
\text { between groups un terms of } \\
\text { attitudes towards almost half of } \\
\text { the brands examined. }\end{array}$ \\
\hline $\begin{array}{l}\text { Babin \& } \\
\text { Carder } \\
\text { (1996b) }\end{array}$ & $\begin{array}{l}98 \text { college } \\
\text { students }\end{array}$ & $\begin{array}{l}\text { Respondents correctly recognized } \\
\text { brands in movie and could } \\
\text { distinguish them correctly from } \\
\text { brands not present in the movie. }\end{array}$ \\
\hline $\begin{array}{l}\text { DeLorme } \\
\text { et al.(1994) }\end{array}$ & $\begin{array}{l}29 \\
\text { undergraduate } \\
\text { students }\end{array}$ & $\begin{array}{l}\text { Most respondents have positive } \\
\text { attitudes towards implicit } \\
\text { placement; but offence taken } \\
\text { when a brand is considered to be }\end{array}$ \\
\hline
\end{tabular}

\begin{tabular}{|c|c|c|}
\hline & & overexposed in movies. \\
\hline $\begin{array}{l}\text { Karrh } \\
(1994)\end{array}$ & $\begin{array}{l}76 \\
\text { undergraduate } \\
\text { students }\end{array}$ & $\begin{array}{l}\text { Prominent brand placement can } \\
\text { lead to higher recall/recognition. }\end{array}$ \\
\hline $\begin{array}{l}\text { Ong \& } \\
\text { Meri(1994) }\end{array}$ & 75 movie-goers & $\begin{array}{l}\text { Generally positive attitudes } \\
\text { towards the practice of brand } \\
\text { placement; low unaided recall of } \\
\text { brand props with recall ability } \\
\text { and patterns differing greatly } \\
\text { among individual respondents; no } \\
\text { link between recall of placements } \\
\text { in movies and increased purchase } \\
\text { intentions. }\end{array}$ \\
\hline $\begin{array}{l}\text { Saberwahl } \\
\text { et al.(1994) }\end{array}$ & $\begin{array}{l}62 \\
\text { undergraduate } \\
\text { students }\end{array}$ & $\begin{array}{l}\text { Audio-visual placement can lead } \\
\text { to higher levels of recall/ } \\
\text { recognition than visual only } \\
\text { placement. }\end{array}$ \\
\hline $\begin{array}{l}\text { Nebenzahl } \\
\text { \& Secunda } \\
(1993)\end{array}$ & $\begin{array}{l}171 \\
\text { undergraduate } \\
\text { students }\end{array}$ & $\begin{array}{l}\text { Brand placement seen to be an } \\
\text { effective technique; most } \\
\text { respondents had more positive } \\
\text { attitudes towards the practice } \\
\text { than to other more obtrusive } \\
\text { promotional forms; small } \\
\text { minority felt it was deceptive. }\end{array}$ \\
\hline
\end{tabular}

\subsection{Creative Types of Brand Placement}

Studies on the BPL types are one of the most important marketing area. Generally in BPL, the exposure types are classified into two main dimensions: visual and verbal or auditory. A purely visual type of placement involves placing the brand in the background of a show in one of two ways: either through creative placement, which insinuates the brand into the game, such as with outdoor advertisements in street scenes; or through on-set placement, which positions the product on the game set itself, such as food brands placed in kitchen scenes.

The second dimension is auditory or verbal. This type of placement refers to the brand being mentioned in a dialogue. There are also varying degrees of audio placement, depending on the context in which the product is mentioned, the frequency with which it is mentioned, and the emphasis placed on the product name (tone of the voice, place in the dialogue, character speaking at the time, etc.).

And also, Shapiro[19] distinguishes between four types of BPL: BPL that provides only clear visibility (e.g. product or brand name is shown); BPL that is used (e.g. actor drinks a bottle of a Coca-Cola); spoken reference (e.g. actor says: "Gee, I wish I had a Jaguar to show her"); and BPL that provides hands-on use and is mentioned by a main star (e.g. Demi Moore says she loves M\&Ms and eats a bunch of them). Shapiro's first category seems analogous to what we 
call implicit BPL, while the other categories are like integrated BPL with increasing explicitness.

On the contrary, Y. J. Lee[20] analyzed the types of consumers' attitudes on the BPL by Q-method. He categorized the attitudes in three types. The first type is Realistic Supporters, who highly value the realism of BPL and apply reasonable applications to BPL. The second type is Principled Critics, who are highly critical of TV BPL and call for high ethical standards. The third type is Consumption-oriented Supporters, who favor TV BPL and actively apply it in their consumption.

The three types were analyzed through FGI and in-depth interviews to find out about the unique characteristics of each type of audiences in their practical uses of the TV BPL in their everyday lives.

The results showed that Realistic Supporters used BPL for information acquisition and its psychological rewards. Principled Critics showed very limited applications of BPL and Consumption-oriented Supporters most aggressively used BPL. Audience in type three understood the trend, used it for their consumption and experienced high satisfaction level. These results can be useful for classifying the attitudes types on BPL of game users.

In the experimental study of Gupta and Lord[21], they reasoned that characteristics which render a brand placement prominent are likely to attract viewers' attention to the brand-as in advertising where it has been shown that increasing the size of a print ad or of a picture within an ad increases the likelihood that it will attract attention.

Furthermore, they reasoned that a stimulus which occupies a prominent position within a visual field is likely to induce greater recall than those which are more pallid. Based on this reasoning, they used a two-dimensional approach to categorize different types of brand placement. One dimension was mode of presentation (the senses activated by the stimulus) and the other was level of prominence (the extent to which the brand placement possesses characteristics designed to make it a central focus of audience attention). And they used these three modes to represent of presentation: visual only; audio only; and combined audio-visual.

\subsection{Brand Placement in Game}

In relation with the game BPL, there have been few researches so far. BPL in game started to appear as an acclaimed marketing tool intended for strengthening brand recognition as brand and product names were harmonically inserted in conventional TV media and movies.

Especially, the growth of movie-related market and network or cable TV makes the potential of exposure through BPL very high. BPL exposed in movies has been acknowledged as being highly influential in drawing attention because most of the film viewers have deep interest in BPL.

Today, however, advertising-as-entertainment models are getting created a partnership between advertiser and game contents provider. Online media such as sponsored websites, promotional contests and brand placement demonstrate new way of combining advertising and game content. As with the racing car or virtual skateboarder customizations, consumers are as actively involved in branded images as they are in actual content in such a way.

Brand placement literature from movies and TV offer some relevant theories and measure about the effectiveness of these techniques for games, but several differences among media contexts must be considered. Advantages of brand placement in games over films include its capacity to increase involvement due to the reception context(active versus passive), its micro-targeting ability and its longer shelf-life.

In addition, the ability for marketers to place highly targeted brands in games easily and efficiently may also increase consumers' involvement. These differences in media and consumer involvement suggest that new research is needed to examine the use of brand props in games. Technologically and aesthetically, games have changed a great deal since Spacewar, the world's first computer game played with a typewriter and punch cards in the early 1960s.

In the last four decades games have changed formats (from arcades to television consoles to computers) and technology has advanced game-realism from black and white to color, from 2D to 3D graphics, and today, moving rapidly into virtual-reality environments.

The effect of brand placement has been evaluated in accordance with the response of its recall, recognition and attitudes. Considering that brand awareness is a primary goal for advertisers using brand placement, memory-based awareness measures such as recognition or recall are appropriate. However, past research has only examined shortterm memory (directly after the media exposure or day-after recall), and therefore not much is known about the longevity of these brand contacts.

Nelson[22] analyzed gamers' brand attitude. According to the research, game players were readily able to recall about 25 to 30 percent of brands in the short-term and about 10 to 15 percent at a delay. Brands demonstrated recall superiority when they were a major part of game-play or when they were local or new brands, atypical of brands found in games, or relevant to the consumer.

When asked their attitudes toward brand placement, game players were generally positive indicating that they did not consider the practice deceptive and the brands can enhance game-realism. Open-ended comments revealed that players' attitudes, however, depended upon the game genre and how and where the brand appeared.

\section{CREATIVE ANALYSIS OF BRAND PLACEMENT IN GAME}

\subsection{Research Design}

The purpose of this research is to identify the creative types of brand placement in game. To find out the BPL types, the game contents were analyzed in accordance with BPL's exposure creativities. The criteria for exposure creativities 
were based on the prior research. The criteria were included the attention-getting location of BPL, the degree of BPL size, the role of BPL in game contents and the exposed moving image of BPL in screen. These criteria were drawn from the creative guideline for BPL evaluation.

According to the research[23], $72.4 \%$ of the respondents tended to focus on the center of the multimedia screen. Therefore, attention effects are maximized when the BPL or key message is put at the center of the screen. And also, 78.3\% of the subjects were concentrated on the bigger size of brand placement in game. In the role of BPL, 53.6\% of respondents tended to memorize the BPL easily when a BPL roles as a promotion tool in game. Lastly, research said viewers' attentions were heightened when a brand image is moving and a particular place is emphasized. In summary, this study analyzed the BPL creative types of game contents in accordance with these four criteria and categorized its type.

As the results, the creative types of brand placement in game were classified in three ways. They are contextual type, prominent type and independent type. Contextual type is one where the brand is present within the game contents without being formally expressed: it plays a passive role. Prominent type is one where the brand is present within the game contents with being formally expressed: it plays an active role. Independent type is one where the brand is present within the game contents with being formally expressed but it is not related with the program: it plays an additional role.

\subsection{Contextual Type of Brand Placement}

A contextual type is appearing the brand in game contents passively. Following brand placements show the real cases of contextual type.
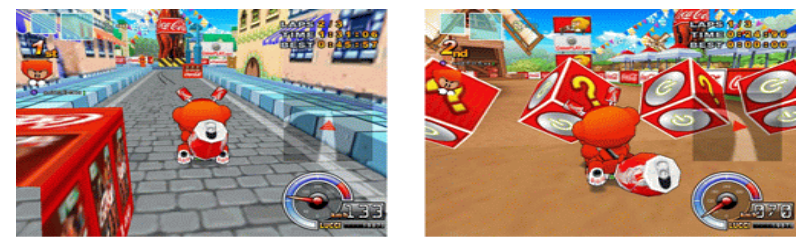

(a) Coca Cola BPL

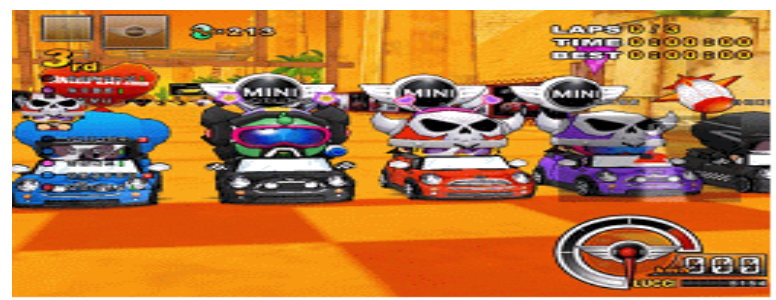

(b) MINI BPL

Fig 1. Kartrider Game BPL

Fig. 1 shows Kartrider BPL. Kartrider is a Korean online multiplayer racing game, developed by Nexon which earns revenues by selling virtual items for the game through its website, including different types of car and spray paint. Coca Cola(confer (a)) is an average of 3 million exposed to Coca
Cola commercial on a daily basis, with each person encountering with Coca Cola brand more than 20 times per day. Such cars include fantasy and real-life models of cars, with Nexon's collaboration with companies such as MINI (confer (b))[24].

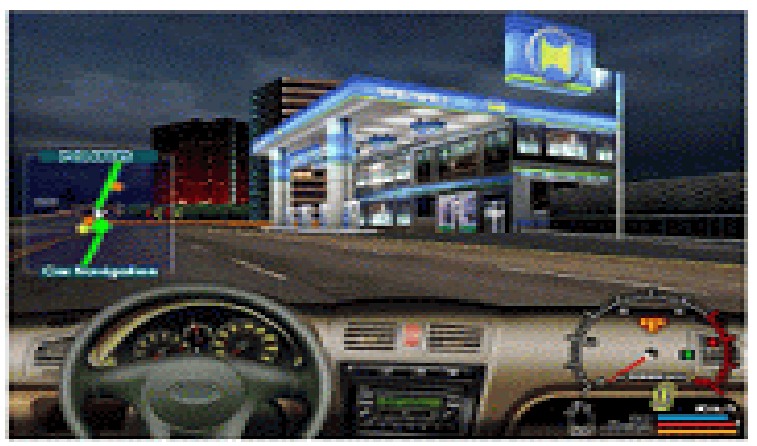

Fig 2. CTRacer Game BPL

Fig. 2 shows CTRacer game(www.ctracer.net) shot. CTRacer online is a 3D game designed for user to easily and quickly engage in high-speed driving through realistic backgrounds of Seoul, Korea. Real Oilbank gas station appears in CTRacer and Seoul station and familiar buildings are one of the important path map for BPL. Such locations do not give any rejections to game players.

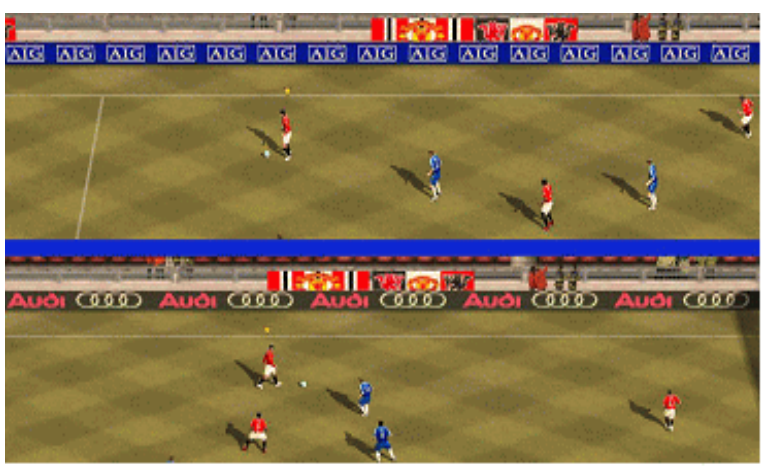

Fig 3. FIFA Game BPL

FIFA (www.fifakorea.net) 2008 case is an example of contextual game BPL. While integrated explicit BPL focuses the brand on uniforms (confer Figure 5. (b)), contextual game BPL shows on signboards around the soccer field.

BPL on-line, as opposed to off-line, has fewer limiting factors such as high budget and long production time. To take examples of online soccer game, client can advertise on the fence around the soccer field as seen Fig. 3.

\subsection{Prominent Type of Brand Placement}

A prominent type of BPL is showing the brand in game program actively. Following brand placements show the real cases of prominent type. 


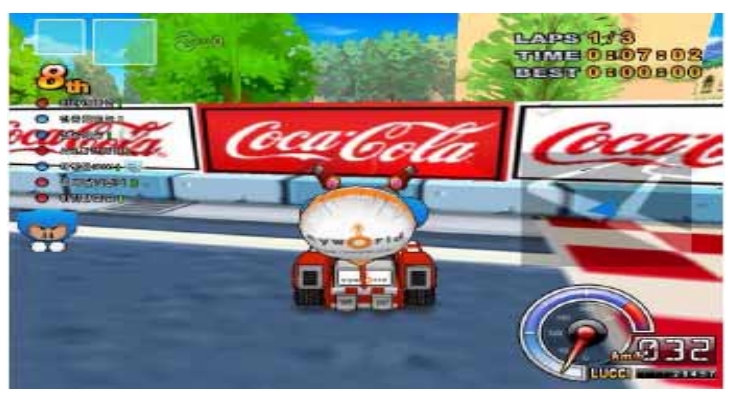

(a) Coca Cola BPL

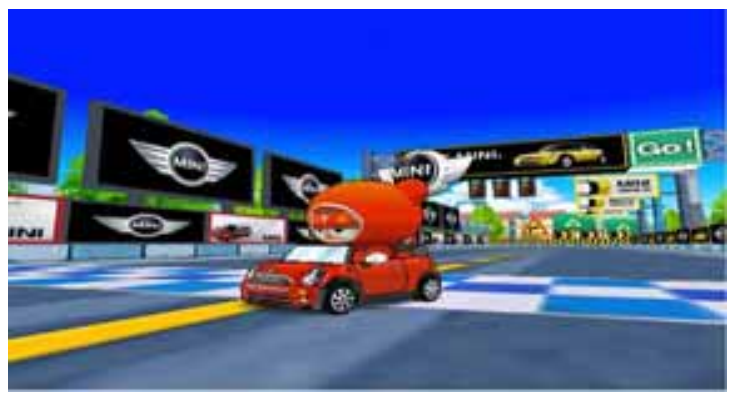

(b) MINI BPL

Fig 4. Kartrider Game BPL

Fig. 4 shows the Kartrider's game BPL which is the type of prominent. The brand on game is more clear and easy to find than that of contextual type.

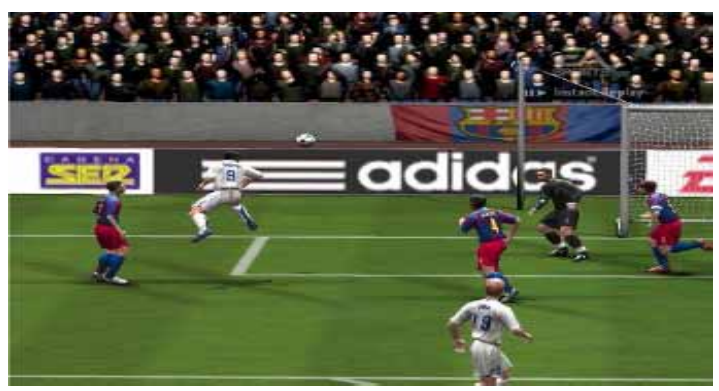

(a) Adidas BPL

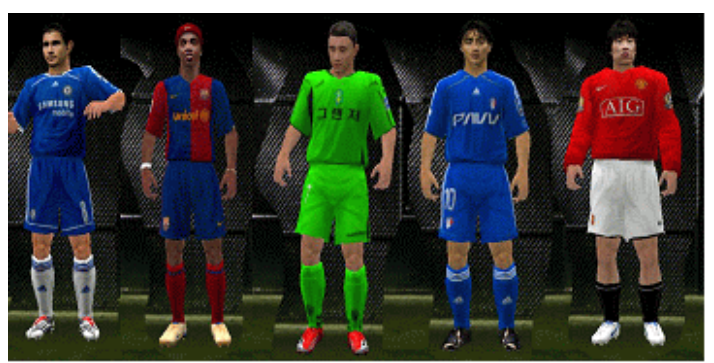

(b) Uniform BPL

Fig 5. FIFA Game BPL

And also, Fig. 5 is a good example of the comparison between the two types of BPL. Fig. (a) and (b) are focused brands on fence and uniforms for easy finding.

In a virtual soccer game as seen Fig. 5, all players can wear uniform and footwear of particular brand. In addition, the unique characteristics of online game make the players feel they have control over the game, which has a benefit of dissolving resistance to BPL unlike in movies or TV programs.
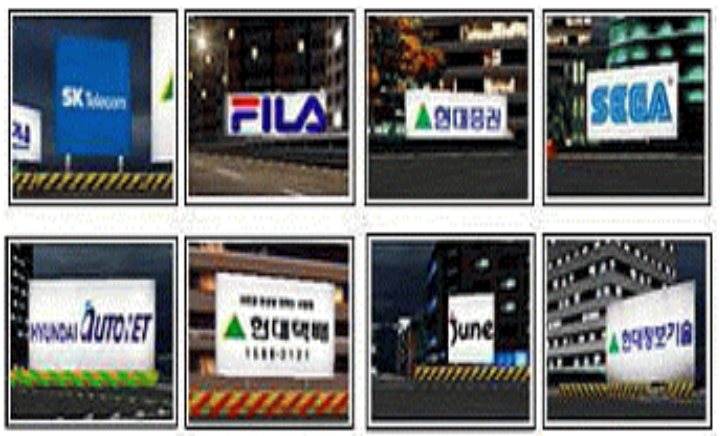

Fig 6. CTRacer Game BPL

Fig. 6 shows CTRacer game shot. CTRacer online is a 3D game designed for user to easily and quickly engage in highspeed driving through realistic backgrounds of Seoul city. The brands on outdoor signboard are also a type of contextual BPL because the brand is present within the game program with being formally expressed and focused.

\subsection{Independent Type of Brand Placement}

An independent type of BPL is one where the brand is present within the game program with being formally expressed but it is not related with the game program.

Fig. 7 shows 'Wangtuggung'(Korean noodle) brand on the game of Special Force(specialforce.pmang.com). Special Force was developed by Dragon-fly in Korea. FPS games are estranged from advertising company because the games' background is war or arms. However, FPS games need a viewers' concentration for raising accommodation rate of game players. Therefore, advertisers want to join their BPL on the FPS games. Through this game, advertiser secured around 400,000 memberships on 'Wangtuggung' website and 1.5 million people participated in the event.

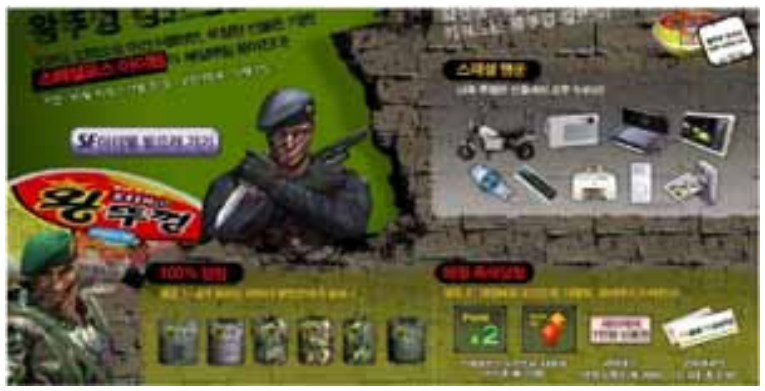

Fig 7. Special Force Game BPL 


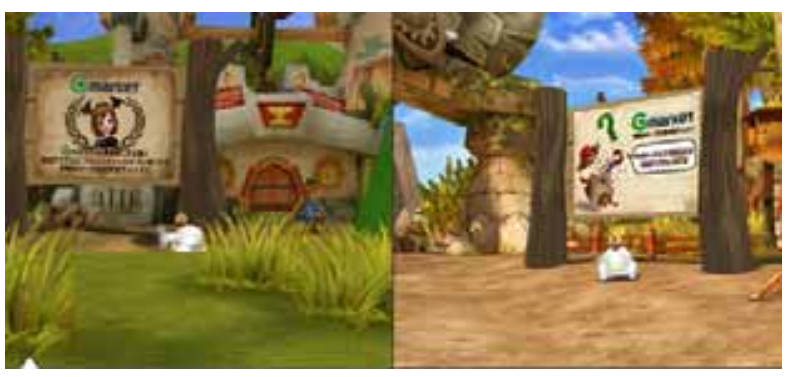

Fig 8. Japanese Game BPL

Fig. 8 shows Japanese game BPL on G market which is Korean online shopping mall. The brand is present within the game program but it is not integrated within the game contents.

\section{CONCLUSIONS}

This paper addressed the issue of brand placement in game. For more detailed discussion, this study analyzed the creative types of brand placement in game. As the results, three creative types of brand placement are found. The types are classified in accordance with BPL creative exposure styles. Among the types, a prominent type is becoming mainstream of BPL in game because of its effectiveness. It means the creative size of BPL in game has been growing and getting center-oriented. This trend reflects the BPL can be a good beneficiary model in game industry.

Especially, brand placement in game is gaining more and more popularity since it is more attention-gathering than in movies or TV. Game requires interaction and sensory immersion of the user each game occurrence provides different experience and the user performs an active role in games and owns the particular brand of gamers' choices unlike in movies or TV programs. In addition, competitive nature of game makes the user spend far longer time than in films, which is related to increased attention on brand. Due to unique characteristics of game, BPL is more likely to appear in a repetitive pattern and the interactive nature of games makes it more attention-holding than BPL in movies or TV. It is thought that BPL game could easily surpass the benefits of BPL in movies or TV.

And also, game developers can benefit in terms of production and the advertisers are able to build up their brand image. And also, game developers sell their ideas to game publishers who are responsible for marketing and distribution. In recent years, the growing economic opportunities within the game industry have resulted in more developers and increased competition. In addition to licensing, developers can include brands within games in many ways, from passive background props to active forms such as equipment and characters.

Therefore, this study is to find out how the brand placement is able to contribute to game industry. In other words, this research summarized the advertising function of BPL as a new beneficiary model in game industry.

And also this study, which is an interdisciplinary in nature, could be found in the fact that it is the pioneering work which applies advertising concepts to the game industry. In advertising fields, BPL is widely accepted which aims at overcoming the weaknesses of conventional commercials which are prone to low attention-gathering.

In conclusion, there has been an increase in the practice of brand placement which is planned entries of brands into media. Therefore, BPL researches to the present have largely focused on proving the effects of BPL by measuring recognition of brand which is exposed in movie and TV programs. This research, however, tries various attempts to identify the creative types of BPL in game. Especially, this research, not to mention simple measurement of brand awareness, aims at more contents analysis of exposure style in game BPL. This approach can be utilized in organizing and managing the BPL in game for maximizing interactions with consumers.

\section{REFERENCES}

[1] Dailyfocus April 5th, 2007. (http://fnn.freechal.com /fnn/content?dst=/template/service/ebook.jsp\&state=seo $\mathrm{ul} \& \mathrm{ct}=101$ )

[2] Gupta, Pola B. \& Kenneth, R. Lord, "Product Placement in Movies: The Effect of Prominence and Mode on Audience Recall“. Journal of Current Issues and Research in Advertising, Vol.20, no1, 1998, pp. 47-59.

[3] d'Astous, A \& Seguin, N., "Consumer Reaction to PPL Strategies in TV sponsorship”. European Journal of Marketing, vol.33, no9, 1999, pp.896-910.

[4] PQ Media. 2005. Product Placement Spending in Media, pqmedia report. 2005.

[5] Nebenzahl, Israel D, \& Eugene, Secunda, "Consumers' Attitudes Toward Product Placement in Movies“, International Journal of Advertising, vol. 12, no 1, 1993, pp. 1-11.

[6] Balasubramanian, S. K., "Beyond Advertising and Publicity. Hybrid Message \& Publicity Policy Issues“, Journal of Advertising. Vol.23, no. 4, 1994, pp.29-46.

[7] Gould, Stephen., \& Gupta, Pola, "Product Placement in Movies", Journal of Advertising. vol.14, no.4, 2000. pp. 41-58.

[8] Saplosky, B.S.\& Kinney, L., "You ought to be in picture:product placements in the top grossing films of 1991”, Proceedings of American Academy of Advertising Conference, 1994, p.89.

[9] Babin, L. A. \& Carder, S. T., "Viewers' Recognition of Brands Placed within a Film“, International Journal of Advertising. vol.15, 1996, pp.140-151.

[10] Gupta, Pola B. \& Kenneth, R. Lord, "Product Placement in Movies: The Effect of Prominence and Mode on Audience Recall”, Journal of Current Issues and Research in Advertising. vol. 20, no.1, 1998, pp.47-59.

[11] d'Astous, A. \& Chartier, F., "A Study of Factors Affecting Consumer Evaluations and Memory of Product Placement in Movies”, Journal of Current Issues and Research in Advertising. Vol. 24, no.2, 2000, pp.28-39.

[12] Gupta, Pola B., Balasubramanian, Silva. K., \& Micheal, L. Klassen, "Viewer's Evaluations of Product Placement in Movies: Public Policy and Managerial Implication“. 
Journal of Current Issues and Research in Advertising. vol.22, no.2, 2000, pp. 41-52.

[13] Steortz, Eva, The Cost Efficiency and Communication Effects Associated with Brand Name Exposure within Motion Pictures, Master's Thesis, West Virginia University, 1987.

[14] Turcotte, S., "Gimme a Bud! The feature film product placement.”, University of Texas at Austin, 1995

[15] Murdock, G, “Branded image”, Sight and Sound(2), July, 103, 1992

[16] Gupta, Pola B. \& Kenneth, R. Lord. "Product Placement in Movies: The Effect of Prominence and Mode on Audience Recall“. Journal of Current Issues and Research in Advertising. 20(1). 1998. pp.47-59.

[17] Babin, L. A. \& Carder, S. T. "Viewers' Recognition of Brands Placed within a Film“. International Journal of Advertising. 15. 1996. pp.140-151.

[18] Lee, Y.J. “Audience Attitudes Types and Their Practical Uses of PPL in TV Drama”, Ph.D. Dissertation, Yonsei University, 2006.

[19] Shapiro, M., "Product placement in motion pictures", Working paper, Northwestern University, 1993.

[20] Lee, Y.J. "Audience Attitudes Types and Their Practical Uses of PPL in TV Drama”, Ph.D. Dissertation, Yonsei University, 2006

[21] Gupta, Pola B. \& Kenneth, R. Lord. 1998. "Product Placement in Movies: The Effect of Prominence and Mode on Audience Recall“. Journal of Current Issues and Research in Advertising. 20(1). 47-59.

[22] Nelson, Michelle, "Recall of Brand Placements Computer/Video Games", Journal of Advertising Research. March/April. 2002, pp.80-92.

[23] Young Jae Lee, "Effective PPL Arrangements in the Screen of Multimedia Contents", Korea Institute of Maritime Information and Communication Science, vol. 11. no5, 2007, pp.875-881.

[24] http://en.wikipedia.org/wiki/Kartrider.

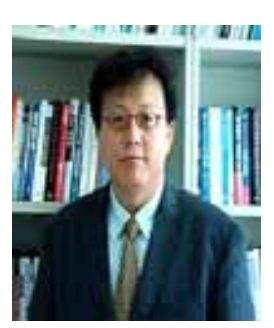

Yong-Jae Lee

He is a professor at the Tongmyong University, in Busan, Korea. After finishing his M.A. at the University of Kansas in USA, he worked at Ogilvy \& Mather, worldwide advertising agency. He received the Ph.D. at the Yonsei University, in Seoul, Korea. His current research interests are focused on brand communication. 